\title{
RELATIONSHIP MARKETING: EXPLORING RELATIONAL STRATEGIES IN MARKETING
}

\author{
Egan, J. (2011). (The 4th Edition) Harlow, England: Prentice Hall, Pearson Education Limited, \\ ISBN 978-0-273-73778-0, XIII+300
}

Katarina Borisavljevic*

Faculty of Economics, University of Kragujevac, Kragujevac, Serbia

In the conditions of globalization and intensive competition, enterprises have increasingly been directing their business operations towards the development of long-term relationships with consumers. Marketing is one of the key business activities of an enterprise, and its basic function is exactly to attract and retain consumers in order for an enterprise to improve its competitive position in the market. This statement is based on the change of the role of the traditional 4P marketing concept (product, price, promotion and place) and the development of a new paradigm within marketing theory known as relationship marketing.

In his book titled: Relationship Marketing: Exploring Relational Strategies in Marketing, John Egan (Director of Marketing \& Communications and Marketing Subject Group Leader at London South Bank University) explores the application of the strategies of relationship marketing in marketing theory and practice, with an aim to build up and improve relationships between enterprises, consumers and other stakeholders in order to satisfy their needs and improve the

* Correspondence to: K. Borisavljevic, Faculty of Economics, University of Kragujevac, Dj. Pucara 3, 34000 Kragujevac, Serbia; e-mail: katarinab@kg.ac.rs enterprise's business performances. For that reason, it is important for enterprises to understand the concept of relationship marketing and to successfully apply strategies of relationship marketing in their business doing so as to maintain and improve their competitive position in the market.

The book consists of three parts: Part One includes sections 1-6; Part Two contains sections 7-10, and Part Three covers sections 11-13. In Part One of the book, the questions of the creation and development of the relationship marketing concept are considered, and the basic assumptions and consequences of the application of relationship marketing strategies in business doing are examined. In Part Two of the book, different types of relationships between enterprises, consumers, employees, offer-makers, and other external stakeholders are analyzed. In Part Three of the book, a special emphasis is put on the role of information technologies in managing relationship marketing strategies. Finally, a conceptual model of the application of relationship marketing in all economic areas is proposed.

In Part One, titled: Relationships (pp. 3-142), the origin of the development of relationship marketing is researched into and similarities and differences 
between transactional marketing and relationship marketing are pointed out. On the basis of the literature reviewed, different definitions of the relationship marketing concept are considered. The assumptions and effects of the application of relationship marketing strategies in business doing are the subject of a special analysis. The efficiency of the implementation of relationship marketing strategies depends, to the greatest extent, on risk factors, emotions, trust, and relatedness between different business entities. Observed from the economic aspect, an increase in consumer's satisfaction and loyalty, the profitability of an enterprise etc. belong to the most significant effects of the application of relationship marketing. A special emphasis in the analysis is put on the explanation of the consumer's satisfaction and loyalty model and the advantages and restrictions of its application in marketing theory and practice.

In Part Two, titled: The core firm and its relationships (pp. 147-224), the results of researches carried out by numerous authors who dealt with the problem of relationship marketing and the analysis of the quality of relationships between enterprises and consumers, employees in an enterprise, different participants in distribution channels, business partners etc. are discussed. In this part, the phases of the consumer relationship management process are explained in order to attract and retain the consumer and increase the profitability of an enterprise. In continuation, the role of internal relationships (internal marketing) in the improvement of an enterprise's performances is pointed out since an increase in the satisfaction of employees should result in an increase in the consumer's loyalty. The management of the relationships between an enterprise and an offer-maker at a vertical level and business partners at a horizontal level of business doing is the subject matter of a special analysis. At the end of this part, the possibilities of an enterprise's cooperation with other external stakeholders (such as governmental and non-governmental agencies, lobby groups, enterprises competitors etc.) are analyzed with the goal of improving the competitive position of all market participants.

Within Part Three of the book, titled: Managing and controlling the relationship (pp. 227-292), the relationship marketing strategies management process is explained and a critical comment on the application of the relationship marketing concept in business doing is presented. The role of information technologies in the personalization of services and the development of relationship marketing is analyzed. The significance of the Internet in doing business and communicating with consumers is particularly highlighted. Apart from that, similarities and differences between the CRM (Customer Relationship Management) concept and relationship marketing, the significance of creating consumer databases and consumer loyalty programs in developing long-term relationships with consumers etc. are pointed out. At the end of this part, the necessity of an enterprise's shifting to the service orientation and a larger implementation of relationship marketing strategies in the service sector is discussed.

In contemporary theory and practice, a scientific discussion on the theme of the application of relationship marketing in an enterprise's business doing is insufficiently developed, which is indicative of the importance and topicality of this book. The scientific contribution the book makes is mirrored in a better understanding of the essence of relationship marketing concepts and relatedness to other marketing concepts such as consumer relationship management, social marketing, an enterprise's service orientation etc.

The book specially puts a stress on the significance of the application of information technologies, particularly regarding the social media, in the implementation of relationship marketing strategies in an enterprise's business doing. On the basis of the carried out analysis of business examples, the book's contribution also lies in stimulating the development of the awareness of the necessity of a broader application of relationship marketing concepts and making recommendations to managers and employees regarding the increasing of consumer loyalty, i.e. an improvement of an enterprise's business performances.

In the book, however, the analysis of the relationship marketing concept is mainly based on theoretical principles so that no empirical exploration of the application of relationship marketing strategies in business doing has been conducted. Due to the specificity of business operations of enterprises 
in different areas (industry, trade, tourism, and so forth), the proposed general conceptual model of the development and successful implementation of relationship marketing strategies is impossible to apply in every enterprise.

$$
\begin{array}{r}
\text { Received on } 27^{\text {th }} \text { November 2013, } \\
\text { after revision, }
\end{array}
$$

Katarina Borisavljevic is a teaching assistant at the Faculty of Economics of University of Kragujevac. She teaches the subjects of Management in Tourism and Hotel-management, and Economics and Organization of Trade Enterprises. She is a student in doctoral academic studies at the Faculty of Economics of Belgrade University. Her main scientific research areas are marketing and management in the service industry. 


\title{
RELATIONSHIP MARKETING: EXPLORING RELATIONAL STRATEGIES IN MARKETING
}

\author{
Egan, J. (2011). (The 4th Edition) Harlow, England: Prentice Hall, Pearson Education Limited, \\ ISBN 978-0-273-73778-0, XIII+300
}

\author{
Katarina Borisavljević*
}

Ekonomski fakultet Univerziteta u Kragujevcu

U uslovima globalizacije i intenzivne konkurencije, preduzeća se u svom poslovanju sve više usmeravaju na razvoj dugoročnih odnosa sa potrošačima. Jedna od ključnih poslovnih aktivnosti preduzeća je marketing, a njegova osnovna funkcija je, upravo, privlačenje i zadržavanje potrošača u cilju poboljšanja konkurentske pozicije preduzeća na tržištu. Ova konstatacija se zasniva na promeni uloge tradicionalnog marketing koncepta 4P (product, price, promotion, place - proizvod, cena, promocija, distribucija) i razvojem nove paradigme u okviru marketing teorije pod nazivom marketing odnosa.

U knjizi, naslovljenoj: Relationship Marketing: Exploring Relational Strategies in Marketing, John Egan (Director of Marketing \& Communications and Marketing Subject Group Leader at London South Bank University) istražuje primenu strategija marketing odnosa u marketing teoriji i praksi, sa ciljem izgradnje i poboljšanja odnosa između preduzeća, potrošača i ostalih stakeholder-a radi zadovoljenja njihovih potreba i unapređenja poslovnih performansi preduzeća. Za preduzeća je važno da razumeju koncept marketing

* Korespondencija: K. Borisavljević, Ekonomski fakultet Univerziteta u Kragujevcu, Đ. Pucara 3, 34000 Kragujevac, Srbija; e-mail: katarinab@kg.ac.rs odnosa i uspešno primenjuju strategije marketing odnosa u svom poslovanju, kako bi održali i poboljšali svoju konkurentsku poziciju na tržištu.

Knjiga se sastoji od tri dela, pri čemu Prvi deo obuhvata sekcije 1-6, Drugi deo sadrži sekcije 7-10, a Treći deo obuhvata sekcije 11-13. U Prvom delu knjige razmatrana su pitanja nastanka i razvoja koncepta marketing odnosa, i ispitane osnovne pretpostavke $\mathrm{i}$ posledice primene strategija marketing odnosa $\mathrm{u}$ poslovanju. U Drugom delu knjige analizirane su različite vrste odnosa između preduzeća, potrošača, zaposlenih, ponuđača i drugih eksternih stakeholder-a. U Trećem delu knjige, poseban naglasak je na ulozi informacionih tehnologija u upravljanju strategijama marketing odnosa. Na kraju, predložen je konceptualni model primene marketing odnosa u svim privrednim oblastima.

U Prvom delu, naslovljenom: Odnosi u ekonomiji $i$ marketingu (3-142 str.), istražuje se poreklo razvoja marketing odnosa i ukazuje na sličnosti i razlike između transakcionog marketinga i marketing odnosa. $\mathrm{Na}$ osnovu pregleda literature, razmatraju se različite definicije koncepta marketing odnosa. Predmet posebne analize su pretpostavke i efekti primene strategija marketing odnosa u poslovanju. Efikasnost 
sprovođenja strategija marketing odnosa zavisi, u najvećoj meri, od faktora rizika, emocija, poverenja i povezanosti između različitih poslovnih subjekata. Posmatrano sa ekonomskog aspekta, u najznačajnije efekte primene marketing odnosa spadaju povećanje satisfakcije i lojalnosti potrošača, profitabilnosti preduzeća i sl. Poseban naglasak $u$ analizi je na objašnjenju modela satisfakcije i lojalnosti potrošača, kao i prednostima i ograničenjima njegove primene $u$ marketing teoriji i praksi.

U Drugom delu, pod naslovom: Preduzeće i njegovi odnosi sa stakeholder-ima (147-224 str.), razmatraju se rezultati istraživanja brojnih autora koji su se bavili problemom marketing odnosa i analizom kvaliteta odnosa između preduzeća i potrošača, zaposlenih u preduzeću, različitih učesnika u kanalima distribucije, poslovnih partnera i sl. U ovom delu objašnjavaju se faze procesa upravljanja odnosima sa potrošačima, $u$ cilju privlačenja i zadržavanja potrošača i povećanja profitabilnosti preduzeća. U nastavku se ukazuje na ulogu internih odnosa (internog marketinga) $u$ poboljšanju performansi preduzeća, jer bi povećanje zadovoljstva zaposlenih trebalo da rezultira povećanjem lojalnosti potrošača. Predmet posebne analize je upravljanje odnosima između preduzeća i ponuđača na vertikalnom nivou, i poslovnih partnera na horizontalnom nivou poslovanja. Na kraju ovog dela analiziraju se mogućnosti saradnje preduzeća sa ostalim eksternim stakeholder-ima (kao što su vladine i nevladine agencije, lobi grupe, konkurentska preduzeća i sl.), sa ciljem poboljšanja konkurentske pozicije svih učesnika na tržištu.

U okviru Trećeg dela knjige, naslovljenog: Upravljanje $i$ kontrola primene marketing odnosa (227-292 str.), objašnjava se proces upravljanja strategijama marketing odnosa i daje kritički osvrt na primenu koncepta marketing odnosa u poslovanju. Analizira se uloga informacionih tehnologija $u$ personalizaciji usluga i razvoju marketing odnosa. Posebno se naglašava značaj interneta u poslovanju i komunikaciji sa potrošačima. Pored toga, ukazuje se na sličnosti i razlike između koncepata upravljanje odnosima sa potrošačima (Customer Relationship Management - CRM) i marketing odnosa, značaj kreiranja baza podataka i programa lojalnosti potrošača $u$ razvoju dugoročnih odnosa sa potrošačima i sl. Na kraju ovog dela, razmatra se neophodnost prelaska preduzeća na uslužnu orijentaciju i veću primenu strategija marketing odnosa u uslužnom sektoru.

U savremenoj teoriji i praksi, naučna diskusija na temu primene marketing odnosa $u$ poslovanju preduzeća je nedovoljno razvijena, što ukazuje na važnost i aktuelnost ove knjige. Naučni doprinos Knjige se ogleda u boljem razumevanju suštine koncepta marketing odnosa i povezanosti sa drugim marketing konceptima, kao što su upravljanje odnosima sa potrošačima, društveni marketing, uslužna orijentacija preduzeća i sl.

U Knjizi je posebno naglašen značaj primene informacionih tehnologija, naročito, društvenih medija, $u$ sprovođenju strategija marketing odnosa $u$ poslovanju preduzeća. Na osnovu sprovedene analize poslovnih primera, doprinos Knjige je i u podsticanju razvoja svesti o neophodnosti šire primene koncepta marketing odnosa i davanju preporuka menadžerima i zaposlenima u povećanju lojalnosti potrošača, odnosno, poboljšanju poslovnih performansi preduzeća.

Međutim, u Knjizi je analiza koncepta marketing odnosa uglavnom zasnovana na teorijskim principima i načelima, tako da nije izvršeno empirijsko istraživanje primene strategija marketing odnosa $\mathrm{u}$ poslovanju. Zbog specifičnosti poslovanja preduzeća iz različitih oblasti (industrije, trgovine, turizma i sl.), predloženi opšti konceptualni model razvoja i uspešnog sprovođenja strategija marketing odnosa nije moguće primeniti u svakom preduzeću. 
Primljeno 27. novembra 2013, nakon revizije, prihvaćeno za publikovanje 17. decembra 2013.

Katarina Borisavljević je asistent na Ekonomskom fakultetu Univerziteta u Kragujevcu, na nastavnim predmetima Menadžment u turizmu i hotelijerstvu i Ekonomika i organizacija trgovinskih preduzeća. Student je doktorskih akademskih studija na Ekonomskom fakultetu Univerziteta u Beogradu. Glavne oblasti naučnog istraživanja su marketing i menadžment u uslužnim delatnostima. 